\title{
Aspek Perlindungan Hukum Terhadap Pembeli Dalam Melakukan Transaksi Jual Beli Melalui Electronic Commerce (Studi Kasus Putusan Pengadilan Nomor 183/Pdt.G/2018/PN.Mdn)
}

\author{
Aspects of Legal Protection Against Buyers in Doing \\ Buying and Selling Transactions Through Electronic Commerce \\ (Case Study of Court Decision No \\ 183/Pdt.G/2018/PN.Mdn)
}

\author{
Warsifah dan David Gurion Napitupulu \\ Sekolah Tinggi Ilmu Hukum IBLAM \\ Kramat Raya No.25, Senen, Jakarta Pusat \\ warsifah@iblam.ac.id, david.napitupulu23@gmail.com
}

\begin{abstract}
The development of technological advances, especially in the development of the internet in Indonesia, apparently also affects business development and the way of transacting in buying and selling transactions through electronic commerce. The use of the internet through e-commerce provides convenience, time efficiency, convenience and so on. Buying and selling transactions through e-commerce are basically the same as conventional buying and selling transactions, but what makes the difference is the media where buyers and sellers meet in buying and selling transactions, namely through the use of the internet in cyberspace. The ecommerce sale and purchase transaction, in the agreement is also the same as the conventional sale and purchase transaction, on the condition that the agreement written in Article 1320 of the Civil Code and the agreed agreement is made in the form of an electronic contract. Often in buying and selling transactions through ecommerce, the party who is harmed is the consumer as the buyer with the contents of the previously agreed agreement not being implemented properly by the seller. These violations range from defaults to consumer disputes. By studying and analyzing case studies in the results of court decisions number 183/Pdt.G/2018/PN.Mdn, it aims to find out the judge's considerations and the legal relationship between the buyer as the Plaintiff and the Defendant and to know aspects of legal protection for the buyer in making a sale transaction. buy through e-commerce.
\end{abstract}

Keywords: electronic commerce, transactions, buying and selling, buyers, sellers

\section{Abstrak}

Perkembangan kemajuan teknologi khususnya dalam perkembangan internet di Indonesia, ternyata juga mempengaruhi perkembangan bisnis dan cara 
bertransaksi dalam melakukan transaksi jual beli melalui electronic commerce. Penggunaan internet melalui e-commerce memberikan kemudahan, efesiensi waktu, kenyamanan dan lain sebagainya. Transaksi jual beli melalui e-commerce pada dasarnya sama dengan transaksi jual beli secara konvensional, namun yang membedakan adalah media dimana pembeli dan penjual bertemu dalam melakukan transaksi jual beli yaitu melalui penggunaan internet dalam dunia maya. Transaksi jual beli e-commerce, dalam perjanjiannya juga sama dengan transaksi jual beli secara konvensional dengan syarat sahnya perjanjian yang tertulis dalam Pasal 1320 Kitab Undang-Undang Hukum Perdata dan perjanjian yang telah disepakati dibuat dalam bentuk kontrak elektronik. Seringkali dalam transaksi jual beli melalui e-commerce, pihak yang dirugikan adalah konsumen sebagai pembeli dengan isi dalam perjanjian yang telah disepakati sebelumnya tidak dilaksanakan dengan baik oleh pihak penjual. Berbagai pelanggaran tersebut dengan adanya wanprestasi sampai dengan sengketa konsumen. Dengan mempelajari dan menganalisa studi kasus dalam hasil penetapan putusan pengadilan nomor 183/Pdt.G/2018/PN.Mdn, bertujuan untuk mengetahui pertimbangan hakim dan hubungan hukum antara pembeli sebagai Penggugat dengan pihak Tergugat serta mengetahui aspek perlindungan hukum bagi pembeli dalam melakukan transaksi jual beli melalui e-commerce.

Kata kunci : electronic commerce, transaksi, jual beli, pembeli, penjual

\section{A. Pendahuluan}

Syarat sahnya perjanjian yang tertuang dalam pasal 1320 Kitab UndangUndang Hukum Perdata adalah dasar dari perjanjian dalam melakukan transaksi secara konvensional. Secara yuridis memang tidak ada yang menjelaskan secara rinci apa yang menjadi syarat sahnya perjanjian dalam transaksi jual beli melalui e-commerce, namun dapat dipahami bahwa syarat sahnya perjanjian yang tertuang dalam Pasal 1320 KUHPerdata tetap berlaku dan menjadi dasar sahnya perjanjian dalam jual beli melalui e-commerce.

Dalam transaksi jual beli melalui e-commerce, perbuatan yang merugikan pembeli melalui adanya wanprestasi sampai dengan sengketa konsumen masih sangat sering terjadi. Adanya penggunaan klausula baku dalam pelaksanaan transaksi elektronik yang dilakukan oleh para pelaku usaha sering mengakibatkan kerugian terhadap konsumen sebagai pembeli. Penggunaan klausul baku sendiri dalam peraturan undang-undang diisyaratkan sangat ketat. Ketentuan sebagaimana dimaksud di atas dalam hal perlindungan konsumen merujuk terhadap UndangUndang Nomor 8 Tahun 1999 Tentang Perlindungan Konsumen, Bab V Pasal 18 mengenai ketentuan pencantuman klausula baku.

Meskipun telah diatur sedemikian rupa untuk melindungi hak-hak konsumen namun penggunaan perjanjian baku dalam transaksi elektronik tetap memiliki resiko kerugian terbesar terhadap konsumen. Perjanjian baku menurut Kelik Wardiono adalah suatu perjanjian yang isinya telah ditetapkan secara sepihak oleh pihak yang pada umumnya mempunyai kedudukan ekonomi lebih kuat, yang diperuntukkan bagi setiap orang yang melibatkan diri dalam perjanjian sejenis itu, 
tanpa memperhatikan perbedaan kondisi antara orang yang satu dengan yang lainnya. ${ }^{1}$ Dari pengertian tersebut dapat dipahami bahwa yang dimaksud dengan pihak yang kedudukan ekonominya lebih kuat adalah para pelaku usaha. Penggunaan perjanjian baku dalam sebuah transaksi e-commerce juga akan mempersempit ruang tawar bagi konsumen. Perjanjian baku juga memberikan sebuah persyaratan yang di rumuskan secara sepihak oleh pihak yang lebih kuat (pelaku usaha).

Permasalahan yang timbul dalam gugatan nomor 183/Pdt.G/2018/PN.Mdn adalah berawal dari pembelian Macbook oleh pembeli dalam hal ini adalah Penggugat terhadap Toko ELIPA Store sebagai e-merchant melalui platform Tokopedia. Pembeli melakuan pembayaran awal dan memang tidak sesuai dengan harga yang tertera dalam invoice yang dikeluarkan oleh Tokopedia, namun dikarenakan adanya ketentuan oleh Tokopedia dimana jika terdapat kurang bayar atas pembayaran yang dilakukan, maka pembeli dapat melakukan transaksi kembali dengan membayar kekurangan tersebut sesuai dengan selisih dari pembayaran dari dana awal terhadap harga resmi suatu barang yang dibeli. Pembeli sudah melakukan sesuai dengan ketentuan dari Tokopedia, namun pembayaran kedua yang dilakukan oleh pembeli dikembalikan oleh Tokopedia dan pembayaran awal yang ditransfer oleh pembeli kepada pihak Tokopedia justru dicairkan kepada pihak lain bukan penjual yang sebelumnya dituju oleh pembeli. Hal ini mengakibatkan kerugian terhadap pembeli atas kelalaian dari pihak Tokopedia, maka pembeli mengajukan gugatan ganti kerugian melalui Pengadilan Negeri Medan dengan nomor perkara 183 Perdata Gugatan pada tahun 2018.

Hubungan hukum yang terjadi dalam pembelian unit barang berdasarkan studi kasus di atas terjalin antara pembeli terhadap penjual dan Tokopedia. Namun yang perlu dipahami bahwa pembeli tidak mendapatkan barang yang dibeli dikarenakan pembayaran awal yang dilakukan tidak dicairkan kepada penjual oleh pihak Tokopedia. Kemudian sistem dari Tokopedia juga tidak mampu memverifikasi pembayaran kedua yang dilakukan pembeli dan mengembalikan dana tersebut kepada pembeli. Jika memperhatikan sedikit dalam kasus tersebut, $e$ merchant yaitu ELIPA STORE tidak memiliki hubungan hukum terhadap pembeli, namun pada kenyataannya, pembeli menghubungi penjual dan mereka menyepakati harga yang telah ditawarkan oleh ELIPA Store sebagai penjual dalam marketplace Tokopedia, bahkan harga yang disepakati antara pembeli dan penjual mempunyai selisih atas harga barang yang telah ditentukan oleh Tokopedia. Tentu hal ini merupakan transaksi di luar dari ketentuan dan syarat dari Tokopedia, namun sudah terjalin hubungan hukum antara pembeli dan penjual yaitu ELIPA Store, hal ini didasarkan pada Pasal 1458 Kitab Undang-Undang Hukum Perdata yang menyatakan bahwa jual beli dianggap telah terjadi antara kedua belah pihak, segera setelah orang-orang itu mencapai kesepakatan tentang barang tersebut beserta harganya, meskipun barang itu belum diserahkan dan harganya belum dibayar.

\footnotetext{
${ }^{1}$ Kelik Wardiono. Perjanjian Baku, Klausula Eksonerasi dan Konsumen: Sebuah Deskripsi Tentang Landasan Normatif, Doktrin dan Praktiknya (Surakarta: UMS Press, 2010), hlm. 7
} 


\section{B. Hasil Penelitian dan Pembahasan}

\section{Syarat Sahnya Perjanjian}

Dalam transaksi jual beli melalui electronic commerce yang dilakukan oleh pembeli terhadap penjual, pada dasarnya memiliki syarat sahnya perjanjian yang sama dengan transaksi jual beli kovensional. Hal yang menjadi dasar syarat sahnya perjanjian tertulis dalam Pasal 1320 Kitab Undang-Undang Hukum Perdata, dimana syarat sahnya perjanjian memiliki 4 (empat) yaitu:

1) Kesepakatan

Kesepakatan adalah sepakatnya para pihak yang menguatkan diri artinya kedua belah pihak dalam suatu perjanjian harus mempunyai kemauan yang bebas untuk mengikatkan diri dan kemauan itu harus dinayatakan dengan tegas atau secara diam. Dengan demikian, suatu perjanjian itu tidak sah apabila dibuat atau didasarkan kepada paksaan, penipuan atau kekhilafan.

2) Kecakapan

Kecakapan adalah adanya kecakapan dalam membuat suatu perjanjian. Menurut hukum, kecakapan termasuk kewenangan untuk melakukan tindakan hukum pada umumnya dan menurut hukum setiap orang yang cakap untuk membuat perjanjian kecuali orang-orang yang menurut undang-undang dinyatakan tidak cakap. Adapun orang-orang tidak cakap membuat perjanjian adalah orang-oang yang belum dewasa, orang yang dibawah pengampuan dan perempuan yang telah kawin.

3) Suatu Hal Tertentu

Menurut Kitab Undang-Undang Hukum Perdata, yang dimaksud dengan suatu hal tertentu dalam syarat sahnya perjanjian adalah:

a. Suatu hal tertentu yang diperjanjikan dalam suatu perjanjian adalah suatu hal atau barang yang cukup jelas atau tertentu, yakni paling sedikit ditentukan jenisnya (pasal 1333 KUH Perdata).

b. Hanya barang-barang yang dapat diperdagangkan saja yang dapat menjadi pokok suatu perjanjian (pasal 1332 KUH Perdata).

4) Sebab yang Halal

Meskipun siapa saja dapat membuat perjanjian apa saja, tetapi ada pengecualiannya yaitu sebuah perjanjian itu tidak boleh bertentangan dengan undang-undang, ketentuan umum, moral dan kesusilaan (pasal 1335 KUH Perdata).

Transaksi jual beli melalui e-commerce dengan terpenuhinya syarat sahnya perjanjian di atas, maka antara pembeli dan penjual akan terikat dalam kontrak elektronik sesuai dengan Pasal 1 butir (17) UndangUndang Nomor 19 Tahun 2016 Tentang Perubahan Atas Undang-Undang Nomor 11 Thaun 2008 Tentang Informasi dan Transaksi Elektronik menyebutkan bahwa kontrak elektronik adalah perjanjian para pihak yang dibuat melalui sistem elektronik.

\section{Hubungan Hukum Dalam Perjanjian}

Hubungan hukum yaitu hubungan yang menimbulkan akibat hukum yang dijamin oleh hukum atau undang-undang. Apabila salah satu pihak tidak 
memenuhi hak dan kewajiban secara sukarela maka salah satu pihak dapat menuntut melalui pengadilan. Suatu perjanjian yang telah disepakati oleh para pihak memliki hubungan hukum yang harus dipatuhi keduanya. Hubungan ini memberikan hak dan kewajiban kepada masing-masing pihak untuk memberikan tuntutan atau memenuhi tuntutan tersebut, artinya tidak akan ada kesepakatan yang mengikat seseorang jika tidak ada perjanjian tertentu yang disepakati oleh para pihak, dari adanya hubungan hukum tersebut, maka timbul tanggungjawab para pihak dalam suatu perjanjian.

Tanggungjawab merupakan realisasi kewajiban terhadap pihak lain, untuk merealisasikan kewajiban tersebut perlu ada pelaksanaan (proses). Hasilnya adalah terpenuhinya hak pihak lain secara sempurna atau secara tidak sempurna. Dikatakan terpenuhinya secara sempurna apabila kewajiban itu dilaksanakan sebagaimana mestinya, sehingga pihak lain memperoleh haknya sebagaimana mestinya pula. Hal ini tidak menimbulkan masalah. Dikatakan tidak terpenuhinya secara sempurna apabila kewajiban itu dilaksanakan tidak sebagaimana mestinya, sehingga pihak lain memperoleh haknya sebagaimana mestinya pula (pihak lain dirugikan), hal ini menimbulkan masalah, yaitu siapa yang bertanggungjawab, artinya siapa yang wajib memikul beban tersebut, pihak debitur atau pihak kreditur, pihak penerima jasa atau pemberi jasa, pihak penjual atau pembeli, dengan adanya pertanggungjawaban ini hak pihak lain diperoleh sebagaimana mestinya (haknya dipulihkan). Jika pihak yang mempunyai kewajiban tidak melaksanakan kewajibannya, ia dikatakan wanprestasi atau ingkar janji. ${ }^{2}$

Wanprestasi atau tidak dipenuhinya janji dapat terjadi baik karena disengaja maupun tidak disengaja. Pihak yang tidak sengaja melakukan perbuatan wanprestasi itu dapat terjadi karena memang tidak mampu untuk memenuhi prestasi tersebut atau juga karena terpaksa untuk tidak melakukan prestasi tersebut. Wanpretasi dapat berupa: ${ }^{3}$

a) Sama sekali tidak memenuhi prestasi.

b) Prestasi yang dilakukan tidak sempurna.

c) Terlambat memenuhi prestasi.

d) Melakukan apa yang dalam perjanjian dilarang untuk dilakukan.

\section{Konsumen dan Pelaku Usaha}

Dalam peraturan perundang-undangan di Indonesia, istilah konsumen sebagai defenisi yuridis formal ditemukan pada Undang-Undang Nomor 8 Tahun 1999 Tentang Perlindungan Konsumen (UUPK). UUPK menyatakan, konsumen adalah setiap orang pemakai barang dan/atau jasa yang tersedia dalam masyarakat, baik bagi kepentingan diri sendiri, keluarga, orang lain maupun makhluk hidup lain dan tidak untuk diperdagangkan.

Konsumen dalam pengertian sehari-hari sering kali dianggap sebagai pembeli (Inggris; buyer, Belanda; koper). Pengertian konsumen secara hukum tidak hanya terbatas kepada pembeli, bahkan jika dicermati dalam pasal 1 ayat (2) UUPK, tidak tertulis kata pembeli. Pengertian pemakai dalam defenisi tersebut di

\footnotetext{
${ }^{2}$ Tood D. Rakoff, Contract of Adhesion an Essay Inreccontruction, 1983, hlm. 1189 Pengertian Wanpretasi, diakses pada 5 Mei 2020 dari http://legalbanking.wordpress.com/materi-hukum/dasar-dasar-hukum-perjanjian/
} 
atas menunjukkan bahwa barang atau jasa dalam rumusan pengertian konsumen tidak harus sebagai hasil dari adanya transaksi jual beli. Dengan demikian, hubungan konsumen dengan pelaku usaha tidak terbatas hanya karena berdasarkan hubungan transaksi atau perjanjian jual beli saja, melainkan lebih dan pada hal tersebut seseorang dapat disebut sebagai konsumen. Namun dalam penulisan penelitian ilmiah ini, yang disebut sebagai konsumen adalah mereka yang melakukan hubungan dengan pelaku usaha berdasarkan hubungan transaksi jual beli saja dalam kegiatan transaksi pada e-commerce, maka konsumen dalam hal ini adalah sebagai pembeli dalam melakukan transaksi jual beli melalui e-commerce.

Produsen sering diartikan sebagai pengusaha yang menghasilkan barang dan jasa. Dalam pengertian ini termasuk di dalamnya pembuat, grosir, leveransir, dan pengecer profesional, yaitu setiap orang/badan yang ikut serta dalam penyediaan barang dan jasa hingga sampai ke tangan konsumen.

Dengan demikian, produsen tidak hanya diartikan sebagai pihak pembuat pabrik yang menghasilkan produk saja, tetapi juga mereka yang terkait dengan penyampaian/peredaran produk hingga sampai ke tangan konsumen. Dengan perkataan lain, dalam konteks perlindungan konsumen produsen dapat diartikan secara luas. Sebagai contoh, dalam hubungannya dengan produk makanan hasil industri (pangan olahan), maka produsennya adalah mereka yang terkait dalam proses pengadaan makanan hasil industri (pangan olahan) itu hingga sampai ke tangan konsumen.

Istilah pelaku usaha merupakan pengertian yuridis dari istilah produsen. Pengertian pelaku usaha juga telah dirumuskan secara khusus dalam Pasal 1 angka (3) Undang-Undang Nomor 8 Tahun 1999 Tentang Perlindungan Konsumen, yaitu pelaku usaha adalah setiap perseorangan atau badan usaha, baik yang berbentuk badan hukum maupun bukan badan hukum yang didirikan dan berkedudukan atau melakukan kegiatan dalam wilayah hukum Negara Republik Indonesia, baik sendiri maupun bersama-sama melalui perjanjian menyelenggarakan kegiatan usaha dalam berbagai bidang ekonomi.

Dalam pengertian ini, termasuklah perusahaan dalam segala usahanya, seperti Badan Usaha Milik Negara (BUMN), koperasi dan perusahaan swasta baik itu berupa pabrik, importir, pedagang eceran, distributor dan lain sebagainya. Dalam penulisan tulisan ilmiah ini, sebagai penyelenggara kegiatan usaha, pelaku usaha yang dimaksudkan adalah para penjual yang melakukan kegiatan transaksi jual beli dalam penjualan berupa barang melalui platform $e$-commerce dan $e$ merchant, dimana mereka menjadi pihak yang bertanggung jawab atas akibatakibat negatif berupa kerugian yang ditimbulkan oleh usahanya terhadap konsumen.

\section{Penutup}

Transaksi jual beli melalui e-commerce merupakan transaksi jual beli yang memakai internet sebagai media dan sarana dalam melakukan kegiatan tersebut. Hubungan hukum yang terjalin antara pembeli dan penjual dalam transaksi jual beli melalui e-commerce pada dasarnya memakai Pasal 1320 KUHPerdata tentang syarat sahnya perjanjian, kemudian dari hasil perjanjian tersebut, maka hubungan hukum yang terjalin dilanjutkan dengan dibuatnya kontrak elektronik antara 
pembeli dan penjual. Dalam penulisan penelitian ilmiah ini, konsumen disebut sebagai pembeli dan pelaku usaha disebut sebagai penjual.

Konsumen dalam hal ini disebut sebagai pembeli harus lebih memahami mengenai syarat sahnya perjanjian dan memahami tentang klausula baku yang diberlakukan oleh penjual demi menghindari kerugian yang disebabkan oleh tindak kelalaian yang dilakukan oleh pelaku usaha sebagai penjual dalam transaksi jual beli melaui electronic commerce.

\section{Daftar Pustaka}

Achmad Ali. 2011. Menguak Tabir Hukum. Jakarta: Toko Gunung Agung, 2011

Kelik Wardiono. 2010. Klausula Eksonerasi dan Konsumen: Sebuah Deskripsi Tentang Landasan Normatif, Doktrin dan Praktiknya. Surakarta: UMS Press.

Setiono. 2011. Supremasi Hukum. Surakarta: UNS.

Nofie Iman. 2010. Pokok-Pokok Transaksi E-Commerce. Jakarta: Grasindo

Tood D. Rakoff, Contract of Adhesion an Essay Inreccontruction, 1983, hlm. 1189 